\title{
PENINGKATAN KAPASITAS PETANI MELALUI PELATIHAN PERAWATAN DAN PEMELIHARAAN BUDIDAYA JAMUR TIRAM
}

\author{
Sri Puji Astuti ${ }^{1{ }^{*}}$, Siti Rosida ${ }^{2)}$, Raudatul Jannati ${ }^{2)}$, dan Ni made Ariana Regita Ulan $\mathrm{D}^{2)}$ \\ 1)Fakultas Matematika dan Ilmu Pengetahuan Alam, Universitas Mataram, \\ 2)Fakultas Keguruan dan IImu Pendidikan, Universitas Mataram \\ ${ }^{*}$ Korespondensi: spastuti@unram.ac.id
}

Diterima 18 Juni 2019 / Disetujui 25 Juli 2019

\begin{abstract}
ABSTRAK
Tujuan kegiatan pengabdian kepada masyarakat ini untuk mensosialisasikan pentingnya cara merawat dan memelihara budidaya jamur tiram agar terhindah dari hama dan serangga, dengan khalayak sasaran masyarakat di desa Tanjung Gunung kelurahan Gerung Selatan. Metode Applied Group Discuss (AGD) yang digunakan mencakup kegiatan ceramah, demonstrasi dan praktik, pembinaan dan evaluasi. Materi kegiatan meliputi teknik perawatan kumbung jamur, penyiangan baglog, pemeliharaan pertumbuhan jamur dan teknik pemanenan. Diakhir kegiatan dilakukan evaluasi melalui observasi diperoleh sebanyak $80 \%$ peserta memahami materi yang disampaikan, sebanyak 65\% peserta memahami teknik perawatan dan pemeliharaan jamur tiram, dan sebanyak $70 \%$ peserta termotivasi untuk menerapkan hasil pelatihan pada usaha budidaya jamur tiram mereka.
\end{abstract}

Kata kunci: perawatan dan pemeliharaan jamur tiram, desa Tanjung Gunung, Lombok Barat

\section{PENDAHULUAN}

Jamur merupakan salah satu jenis sayuran yang banyak mengandung vitamin dan protein yang penting bagi tubuh manusia. Jamur tiram sering dimanfaatkan sebagai sayuran dan lauk alternatif, mengingat banyaknya manfaat dari jamur dan tingginya permintaan pasar mendorong sebagian masyarakat untuk membudidayakan jamur. Salah satu jamur yang banyak dibudidayakan adalah jamur tiram putih (Pleurotus ostreatus).

Budidaya jamur tiram tidak lepas dari kendala yang dihadapi oleh para petaninya, terlebih usaha budidaya jamur tiram seringkali mengalami kegagalan panen karena mudahnya terinfeksi oleh hama atau serangga sehingga banyak jamur yang tidak lulus sortir untuk dipasarkan, umumnya kegagalan budidaya jamur tiram ini dikarenakan teknik budidaya yang kurang tepat dan kurangnya pengetahuan petani terhadap teknik perawatan selama fase pertumbuhan dan perkembangan jamur tiram. Meskipun terlihat mudah, namun pemeliharaan pada faktor-faktor lingkungan, kebersihan, serta konsistensi selama perawatan perlu mendapat perhatian. Jika faktor-faktor tersebut tidak dapat dipenuhi dengan baik, maka akan berpengaruh terhadap jumlah panen dan kualitas jamur yang dihasilkan, bahkan besar 
kemungkinan berpotensi mendatangkan kegagalan. Oleh sebab itu, para petani harus memiliki pengetahuan khusus terhadap teknik perawatan dan pemeliharaan budidaya jamur tiram.

Uraian masalah yang dihadapi oleh petani budidaya jamur tiram diantaranya: (1). teknik budidaya jamur tiram masih bersifat tradisional tanpa memperhatikan faktor kebersihan kumbung, (2). minimnya pengetahuan petani terhadap faktor lingkungan dan kebersihan sebagai salah satu pokok penentu keberhasilan pertumbuhan jamur. (3). minimnya pengetahuan petani terhadap masa dan kondisi baglog untuk digunakan kembali sebagai media budidaya, (4) menurunnya hasil panen jamur setiap pekannya (5) menurunnya kualitas jamur tiram yang dihasilkan sehingga tidak mampu lulus sortir di tingkat pasar modern.

Harapan dengan adanya kegiatan PPM ini adalah: (1). meningkatnya pengetahuan petani jamur mengenai metode budidaya jamur tiram yang lebih modern dan simple untuk diterapkan, (2). Meningkatnya pengetahuan petani terhadap pentingnya kebersihan kumbung jamur dan lingkungan sekitar kumbung, (3). Transfer ilmu dan teknologi kepada petani mengenai teknik perawatan baglog jamur dalam memperpanjang umur baglog dan pemanfaatan baglog afkir. (4). mampu meningkatkan jumlah bongkol jamur tiram sehingga hasil panen jamur tiram lebih banyak, (5). mampu meningkatkan kualitas jamur tiram menjadi lebih besar dan warnamya lebih putih (tidak kuning).

\section{METODE KEGIATAN}

Pelatihan perawatan dan pemeliharaan jamur tiram ini melibatkan peserta dari para petani pembudidaya jamur, pemuda dan masyarakat disekitar desa Tanjung Gunung, mitra jamur lombok dengan latar belakang pengalaman dalam praktik teknik perawatan dan pemeliharaan, tim PPM Unram dengan latar belakang keilmuan yang relevan dengan kebutuhan dan materi pelatihan yang disampaikan mengenai urgensi kebersihan kumbung, kriteria dan kualitas jamur tiram yang dapat bersaing di pasar modern, mahasiswa Kelompok Kerja Nyata (KKN) tematik yang membantu dalam proses administrasi, persiapan, memfasiltasi kegiatan dengan para peserta, dan membantu dalam proses sosialisasi, praktik dan mengumpulan data hasil evaluasi.

Kegiatan ini mengaplikasikan teknik Applied Group Discuss (AGD) untuk memudahkan tersampaikannya informasi dan teknologi yang menjadi tujuan kegiatan ini, selain itu memudahkan dalam diskusi dan evaluasi kegiatan.

Tahap sosialisasi yang dirangkai dengan tahapan praktik perawatan dan pemeliharaan budidaya jamur tiram, meliputi:

\section{Tahapan perawatan}

1. Membersihkan kumbung dan rak-rak dari kotoran untuk menyimpan baglog

2. melakukan penyemprotan fungisida dibagian dalam kumbung dan inkubasi selama dua hari sebelum baglog dimasukan dalam kumbung

3. memasukan dan menata baglog pada arak-rak yang sudah siap.

4. Sebelum baglog disusun, buka terlebih dahulu cincin dan kertas penutup baglog. Kemudian diamkan kurang lebih 5 hari. Bila lantai tersebut tebuat dari tanah lakukan penyiraman untuk menambah kelembaban, dan memperhatikan waktu buka tutup jendela kumbung untuk mempertahankan suhu optimum kumbung 
5. Setelah itu potong ujung baglog untuk memberikan ruang pertumbuhan lebih lebar dan dibiarkan selama 3 hari tanpa diberikan penyiraman

6. Melakukan penyiraman selama 2-3 kali sehari, untuk menjaga kelembaban baglog

\section{Tahap pemeliharaan}

1. Menjaga kelembaban kumbung agar terhindar dari hama, serangga dan jamur parasit

2. menghindari penggunaan atap berbahan asbes dan seng karena dapat meningkatkan suhu lebih cepat

3. Rutin memperhatikan arah pertumbuhan jamur, dan mengankat sisa-sisa jamur yang masih melekat di baglog untuk menjaga pertumbuhan jamur berikutnya lebih bagus

4. Merawat masa penggunaan baglog dengan baik agar jamur yang akan dipanen lulus sortir dan dapat dipasarkan.

Monitoring dan evaluasi dilakukan terhadap ketercapaian tujuan dan sasaran kegiatan PPM, melalui observasi dan wawancara terhadap perserta kegaiatan. Proses ini berlangsung sebelum, saat dan sesudah kegiatan PPM.

Hasil evaluasi menjadi tolok ukur batasan materi pendampingan yang diberikan kepada para peserta PPM.

\section{HASIL DAN PEMBAHASAN}

Kegiatan PPM peningkatan kapasitas petani melalui pelatihan perawatan dan pemeliharaan budidaya jamur tiram dengan sasaran para petani jamur, pemuda dan masyarakat desa Tanjung Gunung dikelurahan Gerung Selatan, diawali dengan kegiatan AGD bersama beberapa warga petani jamur mengenai permasalahan teknik dan kendala yang sering mereka hadapi, kegiatan di fasilitasi mahasiswa KKN.

Kegiatan dilanjutkan dengan tahap sosialisasi dan praktik yang melibatkan banyak warga petani jamur, pemuda dan masyarakat desa Tanjung Gunung, persiapan dan fasilitas disediakan oleh mahasiswa, pihak desa Tanjung Gunung dan staf kelurahan Gerung Selatan.

Sosialisasi disampaikan oleh tim PPM dalam hal ini ibu Sri Puji Astuti, selaku narasumber yang memaparkan materi urgensi kebersihan kumbung, kriteria dan kualitas jamur tiram yang dapat bersaing di pasar modern, kegiatan dilanjutkan dengan praktik langsung yang dilakukan di salah satu kumbung jamur milik salah seorang petani jamur tiram.

Sesi praktik disampaikan langsung oleh mitra kegiatan PPM yakni pengusaha Jamur Lombok yang disampaikan oleh bapak Agus Sutisno, pada tahap ini peserta kegiatan bebas bertanya terkait permasalahan yang mereka hadapi, muatan materi sekaligus solusi yang harus dilakukan. Pada tahap ini proses monitoring terus berjalan yang dilakukan oleh para mahasiswa.

Masyarakat desa Tanjung Gunung sangat antusias mengikuti kegiatan PPM dari awal hingga akhir, hal ini terbukti dari pertanyaan-pertanyaan yang diajukan tidak hanya dari para petani jamur tiram sendiri namun pertanyaan juga dating dari mwarga masyarakat yang tidak membudidayakan jamur tiram, justru dengan adanya kegiatan ini, sebagian besar warga optimis untuk memulai usaha budidaya jamur tiram skala rumahan.

Dukungan yang diberikan oleh kepala lurah (bapak Nursalim) beserta jajarannya, tidak sebatas hanya memfasilitasi kegiatan PPM ini, namun memberikan peluang kepada para warganya untuk memulai usaha jamur tiram ini dengan memanfaatkan tanah 
milik desa untuk dijadikan sebagai lahan kumbung jamur tiram yang dikelola secara bersama-sama.

Hasil monitoring kegiatan PPM yang diperoleh dibandingkan dengan capaian indikator yang menjadi target ketercapainnya, hasil monitoring dan evalusi ini menunjukkan bahwa: (1). sebanyak $80 \%$ peserta PPM memahami materi yang disampaikan oleh para narasumber, (2). berdasarkan hasil praktik diperoleh sekitar $65 \%$ peserta memahami teknik perawatan dan pemeliharaan jamur tiram, dan (3). sekitar $70 \%$ peserta sangat termotivasi untuk menerapkan hasil pelatihan pada usaha budidaya jamur tiram milik mereka. Materi praktik perawatan dan pemeliharaan ditampilkan pada Gambar 1-5.

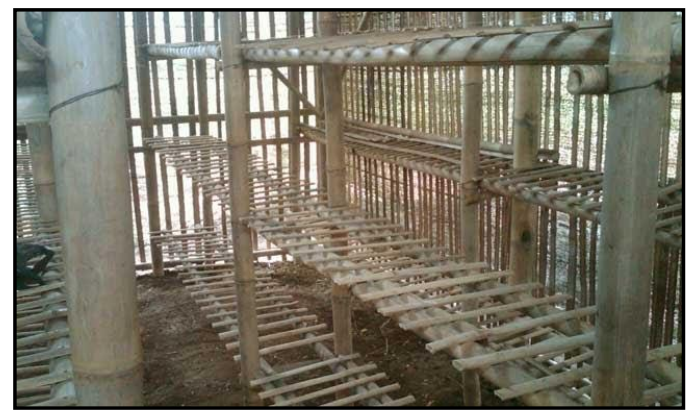

Gambar 1. Rak-rak penyimpanan baglog harus bersih dari kotoran dan sampah.

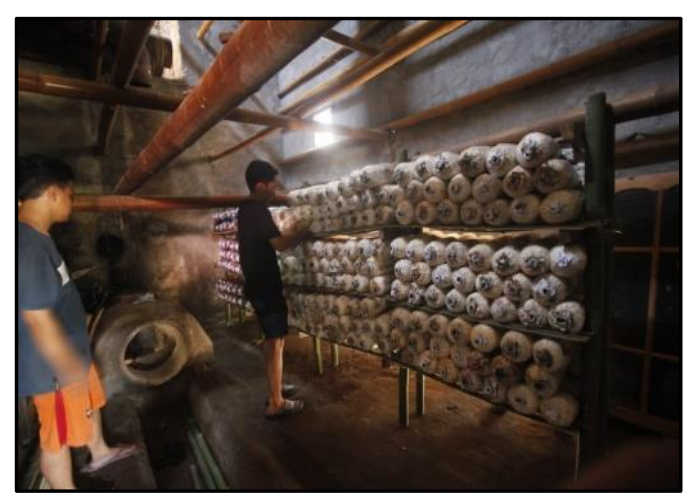

Gambar 2. Memeriksa dan membersihkan baglog dari kotoran yang menepel, serta memeriksa kondisi baglog layak tanam.

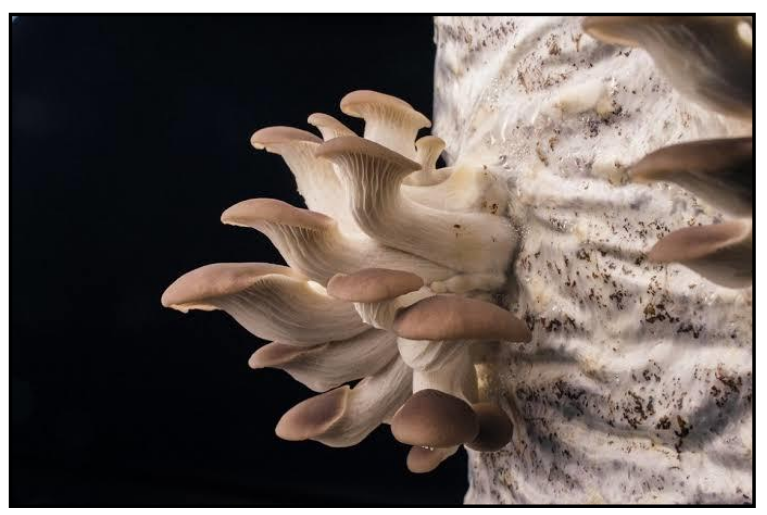

Gambar 3. memeriksa arah dan partumbuhan jamur tiram

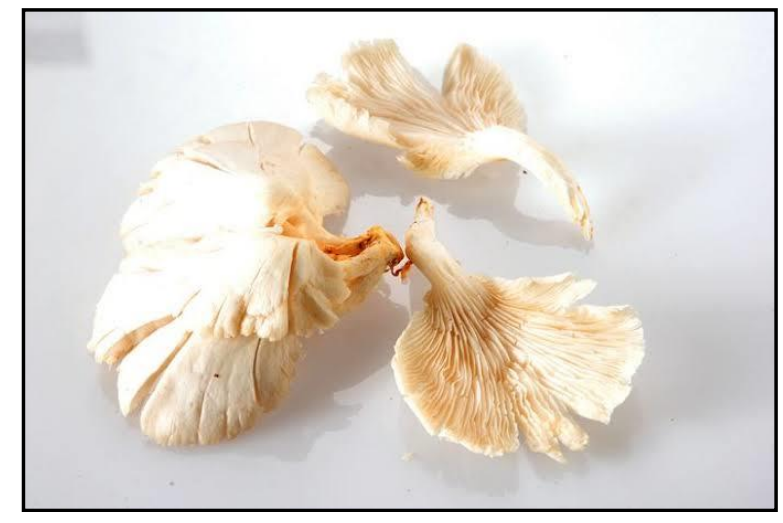

Gambar 4. Contoh jamur tiram yang mengalami pertumbuhan tidak normal, jamur dengan kondisi demikian harus segera dipotong agar tidak mengganggu pertumbuhan jamur dibawahnya.

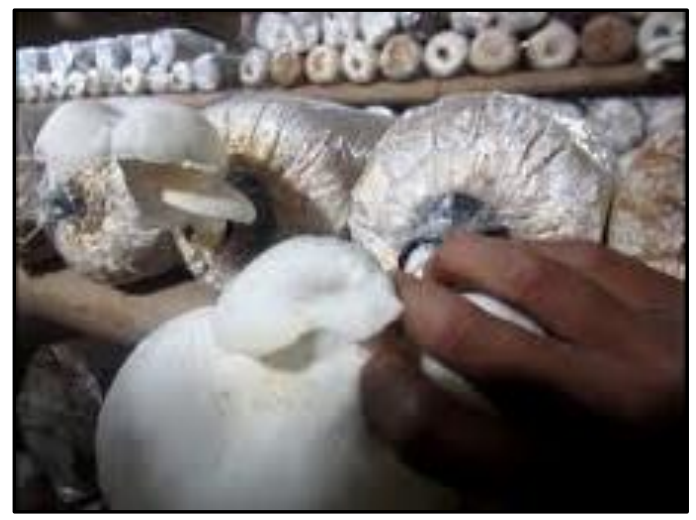

Gambar 5. cara pemanenan jamur tiram dari baglog yang benar 
Adanya pelatihan perawatan dan pemeliharaan pada budidaya jamur tiram ini telah mampu mencapai sasaran yang diharapkan diantaranya: (1). ketercapaian jumlah audience, (2). ketercapaian sasaran kegiatan, (3). ketercapaian pemahaman materi yang diberikan (4). ketercapaian tujuan akhir dari kegiatan ini yakni peserta optimis untuk mempraktikkan kembali materi-materi yang diberikan serta termotivasinya warga untuk mencoba budidaya jamur tiram skala rumah tangga.

\section{KESIMPULAN}

Kesimpulan yang dapat diambil dari kegiatan ini adalah, dengan adanya pelatihan dan praktik langsung, dapat meningkatkan pemahaman para peserta terhadap teknik perawatan dan pemeliharaan jamur tiram yang benar, selain menambah informasi bagi warga secara umum, kegiatan PPM ini secara langsung telah memotivasi warga untuk mencoba sekaligus mempraktikkan dengan cara memulai usaha jamur tiram skala rumah tangga.

\section{DAFTAR PUSTAKA}

Cahyana, Muchrodji dan Bakrun. 1999. Pembibitan, Pembudidayaan dan Analisis UsahaBudidaya Jamur Tiram. Jakarta: Penebar Swadaya.

Hasyim, Fidha. 2015 Budidaya Jamur Tiram. Yogyakarta.

Sinaga. 1993. Jamur Tiram dan Budidayanya. Jakarta: Penebar Swadaya. 